\title{
Evaluation of knowledge, attitudes and practices of health services vocational schools' students with regard to COVID-19
}

Serhat Sirekbasan, ${ }^{1 *}$ Aysegul Oglakci Ilhan ${ }^{1}$ and Canan Baydemir ${ }^{2}$

${ }^{1}$ Department of Medical Laboratory Techniques, Eldivan Health Services Vocational School, Çankırı Karatekin University, Çankırı, Turkey; ${ }^{2}$ Department of Biostatistics and Medical Informatics, Faculty of Medicine, Kocaeli University, Kocaeli, Turkey

\begin{abstract}
Introduction: The most critical intervention to control SARS-CoV-2 infection requires appropriate knowledge and attitude towards the virus. Objective: To determine the level of knowledge, attitudes and practices of students of a health services' vocational school with regard to COVID-19. Methods: Cross-sectional study carried out between May and June 2020 in a university of the Turkish region. Data were collected through an online survey portal. Results: Four hundred and fifty-four questionnaires were completed and returned. Students of medical laboratory techniques and first aid and emergency medicine had significantly higher knowledge scores $(p<0.001)$. More than $43 \%$ of the students $(n=201)$ used the TV as their main source of information on COVID-19. There was a positive attitude towards preventive measures such as avoiding crowded places and maintaining hand hygiene and social distance. Conclusions: Health services vocational school students have good knowledge and positive attitude towards COVID-19. The main sources of information were the TV and social media. For this reason, more attention should be given to these issues in the curriculum in order for science-based information sources to be used.
\end{abstract}

KEY WORDS: Attitude. Coronavirus. COVID-19. Knowledge. SARS-CoV-2.

\section{Evaluación de los conocimientos, actitudes y prácticas de los estudiantes de escuelas vocacionales de servicios de salud respecto a COVID-19}

\section{Resumen}

Introducción: La intervención más crítica para controlar la infección por SARS-CoV-2 requiere el conocimiento y la actitud correctos hacia el virus. Objetivo: Determinar el conocimiento, las actitudes y las prácticas de los estudiantes de una escuela vocacional de servicios de salud respecto a COVID-19. Métodos: Estudio transversal realizado entre mayo y junio de 2020 en una universidad de la región de Turquía. Los datos se recopilaron mediante un portal de encuestas en línea. Resultados: Se completaron y devolvieron 454 cuestionarios. Los estudiantes de técnicas de laboratorio médico y primeros auxilios y emergencias tuvieron puntuaciones de conocimiento significativamente más altas $(p<0.001)$. Más de $43 \%$ de los estudiantes $(n=201)$ usaron televisores como su principal fuente de información sobre COVID-19. Se manifestó una actitud positiva hacia las aplicaciones, así como evitar lugares concurridos y mantener la higiene de las manos y la distancia social. Conclusiones: Los estudiantes de la escuela vocacional de servicios de salud tienen buen conocimiento y actitud positiva hacia COVID-19. Las principales fuentes de información fueron la televisión y las redes sociales, por lo que se debe prestar más atención a estos temas en el plan de estudios para utilizar fuentes de información basadas en la ciencia.

PALABRAS CLAVE: Actitud. Coronavirus. COVID-19. Conocimiento. SARS-COV-2.

\footnotetext{
Correspondence:

0016-3813/O 2020 Academia Nacional de Medicina de México, A.C. Published by Permanyer. This is an open acce license (http://creativecommons.org/licenses/by-nc-nd/4.0/).
} 


\section{Introduction}

Coronaviruses have been identified for decades and are generally relatively harmless respiratory pathogens. However, after the emergence of severe acute respiratory syndrome (SARS) in 2002, and the appearance of Middle East respiratory syndrome (MERS) in 2017, they have attracted attention as important pathogens in respiratory infections. ${ }^{1} \mathrm{~A}$ member of this family of viruses was established as the cause of the epidemic that emerged in Wuhan, China, in December 2019, and became a global threat that affects the entire world. $^{2,3}$

Coronavirus disease 2019, also known as COVID-19, is caused by a new human coronavirus called SARS-CoV-2, and has rapidly spread around the world. By June 25, 2020, more than 9.2 million confirmed cases and 478,691 deaths had been reported worldwide. ${ }^{4}$ COVID-19 is transmitted from person to person through respiratory droplets, by oral contact with contaminated fecal residues, and by direct contact with an infected person. ${ }^{5}$ So far, there are no curative antiviral treatments or recommended vaccines against COVID-19, which has an incubation period of two to 14 days. ${ }^{6,7}$ There is a strong relationship between disease severity increase and mortality in older adults and patients with comorbidities such as hypertension, heart disease, lung disease, cancer, or diabetes. The disease is highly contagious, and its main clinical symptoms are fever, dry cough, fatigue, muscle pain, and dyspnea. ${ }^{8,9}$

The most critical intervention to control SARSCoV-2 infection is to apply common preventive measures that are used to avoid infection with other respiratory viruses. Social distancing is the first one of them. People should avoid contact with infected people, especially due to the infectious nature of the virus. It is also important for people to wash their hands with soap and water for at least 30 seconds, or use hand sanitizers in the absence of soap and water. $^{10-12}$

The knowledge and attitudes of students of health services' vocational schools, who will be part of the health system in the future, highly important in terms of infection prevention. During possible epidemic periods, showing a positive attitude towards preventing the transmission of infectious agents provides a unique opportunity to fight disease. Therefore, the purpose of our study is to determine the levels of knowledge and attitudes towards COVID-19 and to evaluate the behavior of said students. Our study is the first one on the subject.

\section{Methods}

Cross-sectional study conducted between May and June 2020 at a university in Turkey's Central Anatolia region. The research examined students from the health services vocational departments of the university. The sample was composed of those individuals who voluntarily agreed to participate.

An online survey was developed for the research, the validity and reliability of which was assessed prior to its use. In the first step, expert opinions were used to ensure the validity of the content of the statements in the group of questions. In the second step, a pilot study was carried out with 11 students to validate the questionnaire; the results were consistent.

The research data were collected through Microsoft Forms (https://forms.office.com/), an online survey portal. The link to the survey was shared with student groups via WhatsApp, and an invitation to participate in the study was sent. On the first page of the survey, students were informed about the study, stating that participation was voluntary. The survey consists of 31 questions, which take approximately six minutes to be answered.

The survey contains four sections on awareness (knowledge) and attitude regarding the COVID-19 pandemic. The first section includes the characteristics of participants (age, gender and the program they are studying in); the second includes questions about awareness on COVID-19 (15 questions); the third one refers to sources of information about COVID-19 (one question) and the fourth section contains questions about attitudes and practices (10 questions).

Statistical evaluations were performed using the IBM SPSS software package, version 20.0 (IBM Corp., Armonk, NY, USA). Compliance of data with a normal distribution was evaluated using the Shapiro-Wilk test. Numerical variables are described as medians $\left(25^{\text {th }}\right.$ $75^{\text {th }}$ percentile) and frequencies (percentages). As for numerical variables that did not have a normal distribution, the difference between groups or materials was compared using Mann-Whitney's U-test; Fisher's exact chi-square test, Yates chi-square test and Monte Carlo chi-square test were used for categorical variables. The level of statistical significance was established at $p<0.05$ (two sided). 
Table 1. Participants' demographics and knowledge scores

\begin{tabular}{|c|c|c|c|c|c|c|}
\hline \multirow[t]{2}{*}{ Characteristics } & \multicolumn{2}{|c|}{ Participants } & \multicolumn{4}{|c|}{ Knowledge scores } \\
\hline & $\mathrm{n}$ & $\%$ & Median & Mean & SD & p \\
\hline $\begin{array}{l}\text { Gender } \\
\text { Females } \\
\text { Males }\end{array}$ & $\begin{array}{l}316 \\
138\end{array}$ & $\begin{array}{l}69.6 \\
30.4\end{array}$ & $\begin{array}{l}12.80 \\
12.68\end{array}$ & $\begin{array}{l}13 \\
13\end{array}$ & $\begin{array}{l}1.02 \\
1.12\end{array}$ & $0.373^{*}$ \\
\hline $\begin{array}{l}\text { Age group (years) } \\
\leq 18 \\
19-21 \\
22-24 \\
\geq 25\end{array}$ & $\begin{array}{c}22 \\
373 \\
48 \\
11\end{array}$ & $\begin{array}{c}4.8 \\
82.2 \\
10.6 \\
2.4\end{array}$ & $\begin{array}{l}12.64 \\
12.72 \\
13.06 \\
13.09\end{array}$ & $\begin{array}{l}13 \\
13 \\
13 \\
13\end{array}$ & $\begin{array}{l}0.90 \\
1.07 \\
0.93 \\
0.94\end{array}$ & $0.100^{\dagger}$ \\
\hline $\begin{array}{l}\text { Program } \\
\text { Child Development } \\
\text { Elderly Care } \\
\text { Environmental Health } \\
\text { First Aid and Emergency Medicine } \\
\text { Home Patient Care } \\
\text { Laboratory and Veterinary Health } \\
\text { Medical Laboratory Techniques } \\
\text { Optician }\end{array}$ & $\begin{array}{c}69 \\
19 \\
32 \\
152 \\
90 \\
29 \\
30 \\
33\end{array}$ & $\begin{array}{c}15.2 \\
4.2 \\
7.0 \\
33.5 \\
19.8 \\
6.4 \\
6.6 \\
7.3\end{array}$ & $\begin{array}{l}12.33 \\
13.00 \\
12.41 \\
13.08 \\
12.51 \\
12.55 \\
13.40 \\
12.73\end{array}$ & $\begin{array}{c}12 \\
13 \\
12.5 \\
13 \\
13 \\
13 \\
13 \\
13\end{array}$ & $\begin{array}{l}0.98 \\
1.05 \\
1.04 \\
0.92 \\
1.08 \\
1.15 \\
0.81 \\
1.13\end{array}$ & $0.000^{+}$ \\
\hline
\end{tabular}

*Mann-Whitney's U-test. †Kruskal-Wallis test. SD = standard deviation.

The study was approved by the Çankırı Karatekin University Ethics Committee (approval number 2020/210) and permission was obtained from the school management (2020/E.9228); the study was carried out in accordance with the principles of the Declaration of Helsinki. An electronic voluntary informed consent form was displayed on the first page of the questionnaire.

\section{Results}

A total of 460 students completed the questionnaire, out of which six who refused to accept the electronic voluntary informed consent form were excluded. In the final sample $(n=454)$, most participants were between 19 and 21 years old $(n=373$, $82.2 \%$ ). Females accounted for $69.6 \%$ of the sample $(n=316)$. Other demographic characteristics are described in table 1.

Table 2 shows the current status of information on COVID-19 among health vocational college students. The level of knowledge was evaluated by awarding one point for correct and zero for wrong answers. The highest score was 15 and the lowest score was nine. A total of 401 participants (88.3\%) had good scores, but $53(11.7 \%)$ showed insufficient information about COVID-19.

Most respondents had information about infection prevention measures, disease risk factors, and that close contact is effective for spreading the disease. Unexpectedly, most surveyed students believed that the incubation period of the virus was much longer than it actually is. In addition, weak information was most evident in questions regarding the place of antibiotics in first-line treatment and effectiveness of $70 \%$ alcohol, for which the wrong answer rates were 38.1 and $33.3 \%$, respectively. Mean knowledge score was $12.76 \pm 1.05$ (Table 2).

Average total knowledge scores were compared according to students' demographic characteristics (Table 1). There were no statistically significant differences according to age group or gender ( $p>0.05$ ). According to the study programs, the participants who studied medical laboratory techniques and first aid and emergency medicine obtained higher total knowledge scores, with a statistically significant difference between them $(p<0.001)$. Participants who took microbiology courses throughout their education scored higher on the knowledge scale (12.87) than other students (12.69), but the difference was not statistically significant $(p=0.071)$.

The answers showed that the students mainly obtained information from television (Fig. 1). Most participants $(90.4 \%)$ had not attended crowded places in recent days and wore face masks when leaving home $(95.0 \%)$. Despite this, a small segment had recently visited crowded places $(9.6 \%)$ and did not wear a face mask when leaving home (5.0\%). 
Table 2. Health vocational school students' knowledge about COVID-19

\begin{tabular}{|c|c|c|c|c|}
\hline \multirow[t]{2}{*}{ Knowledge about COVID-19 } & \multicolumn{2}{|c|}{$\begin{array}{l}\text { Correct } \\
\text { answer }\end{array}$} & \multicolumn{2}{|c|}{$\begin{array}{l}\text { Incorrect } \\
\text { answer }\end{array}$} \\
\hline & $\mathrm{n}$ & $\%$ & n & $\%$ \\
\hline $\begin{array}{l}\text { Older people and people with } \\
\text { underlying medical conditions such } \\
\text { as hypertension, diabetes, heart } \\
\text { disease and cancer are more likely to } \\
\text { develop serious diseases }\end{array}$ & 453 & 99.8 & 1 & 0.2 \\
\hline $\begin{array}{l}\text { Isolation and treatment of people } \\
\text { infected with the virus is an effective } \\
\text { form to reduce the spread of the } \\
\text { disease. }\end{array}$ & 453 & 99.8 & 1 & 0.2 \\
\hline $\begin{array}{l}\text { People who have contact with an } \\
\text { infected person should immediately } \\
\text { isolate themselves for } 14 \text { days in a } \\
\text { convenient place }\end{array}$ & 452 & 99.6 & 2 & 0.4 \\
\hline $\begin{array}{l}\text { Handwashing with soap and water } \\
\text { for at least } 20 \text { seconds can help } \\
\text { prevent infections }\end{array}$ & 451 & 99.3 & 3 & 0.7 \\
\hline $\begin{array}{l}\text { Severe acute respiratory disease } \\
\text { develops in patients with COVID-19 }\end{array}$ & 450 & 99.1 & 4 & 0.9 \\
\hline $\begin{array}{l}\text { The main source of COVID-19 is a } \\
\text { plant }\end{array}$ & 448 & 98.7 & 6 & 1.3 \\
\hline $\begin{array}{l}\text { Fever, dry cough and shortness of } \\
\text { breath are COVID-19 distinctive } \\
\text { symptoms }\end{array}$ & 446 & 98.2 & 8 & 1.8 \\
\hline $\begin{array}{l}\text { The disease can be transmitted by } \\
\text { patients who are asymptomatic or in } \\
\text { the latent period of the disease }\end{array}$ & 441 & 97.1 & 13 & 2.9 \\
\hline $\begin{array}{l}\text { People with COVID-2019 cannot } \\
\text { infect others when there is no fever }\end{array}$ & 441 & 97.1 & 13 & 2.9 \\
\hline $\begin{array}{l}\text { It is not necessary for children and } \\
\text { young adults to take measures to } \\
\text { prevent COVID-19 transmission }\end{array}$ & 408 & 89.9 & 46 & 10.1 \\
\hline $\begin{array}{l}\text { COVID-19 can be transmitted by fly } \\
\text { bite }\end{array}$ & 370 & 81.5 & 84 & 18.5 \\
\hline $\begin{array}{l}\text { Polymerase chain reaction (PCR) } \\
\text { can be used for the diagnosis of } \\
\text { COVID-19 }\end{array}$ & 332 & 73.1 & 122 & 26.9 \\
\hline $\begin{array}{l}\text { COVID-19 can be eliminated with } \\
70 \% \text { alcohol }\end{array}$ & 303 & 66.7 & 151 & 33.3 \\
\hline Antibiotics are the first-line treatment & 281 & 61.9 & 173 & 38.1 \\
\hline $\begin{array}{l}\text { The incubation period of the virus is } 2 \\
\text { to } 4 \text { weeks }\end{array}$ & 66 & 14.5 & 388 & 85.5 \\
\hline
\end{tabular}

In the section of the questionnaire that addressed attitude, a positive attitude towards practices such as

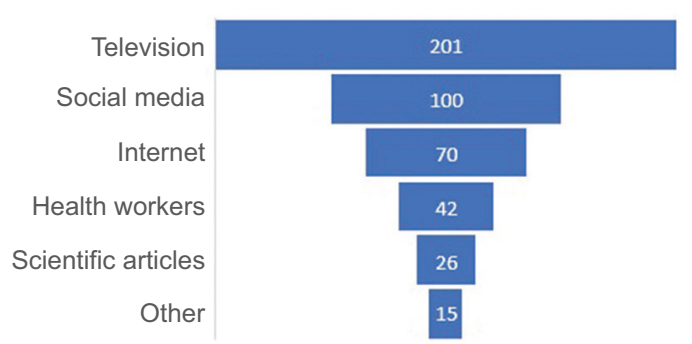

Figure 1. Sources of information about COVID-19 in 454 participants.

frequent environmental and hand hygiene, maintaining social distance and avoiding crowded places was identified. Participants believed that even healthy people should wear face masks and that additional measures should be taken to prevent transmission of the disease. Most participants believed that COVID-19 danger of is not as much as that of seasonal flu. However, half the participants believed that not all people with COVID-19 develop a serious condition (Table 3).

\section{Discussion}

Many studies have examined a variety of information, attitudes, and practices about epidemic infectious diseases caused by coronaviruses such as SARS and MERS. However, to our knowledge, there are no investigations looking into the knowledge and attitudes of health services vocational school students regarding COVID-19. The results of this study showed that these students have good knowledge and a positive attitude towards COVID-19. Most were aware of the condition of the disease, which continues at a pandemic level throughout the world.

It was concluded that the gender and age group variables did not affect total mean scores. In a 2013 systematic review article, Tooher et al..$^{13}$ examined community knowledge, behavior, and attitudes regarding the H1N1 flu epidemic. Their findings support our results, although other investigations have reported that gender and age group affect knowledge and awareness on the pandemic. These differences between studies are believed to be due to the variability of the countries where they were conducted, the factor that causes the pandemic, and the included population.

In addition, participants studying medical laboratory techniques and first aid and emergency programs achieved better COVID-19 knowledge scores than students in other programs. This difference can be explained by the fact that the former have more clinical 
Table 3. Attitude of health vocational education students towards COVID-19

\begin{tabular}{|c|c|c|c|c|c|c|c|c|c|}
\hline \multirow[t]{3}{*}{ Attitudes } & \multicolumn{6}{|c|}{ Answers } & \multicolumn{3}{|c|}{$\mathrm{p}^{\dagger}$} \\
\hline & \multicolumn{2}{|c|}{ A } & \multicolumn{2}{|c|}{$\mathbf{U}$} & \multicolumn{2}{|c|}{ D } & \multirow[t]{2}{*}{ Program } & \multirow[t]{2}{*}{ Gender } & \multirow[t]{2}{*}{ Years } \\
\hline & $n$ & $\%$ & $n$ & $\%$ & $n$ & $\%$ & & & \\
\hline $\begin{array}{l}\text { People should avoid attending crowded places to prevent } \\
\text { COVID-19 contagion }\end{array}$ & 452 & 99.6 & 0 & 0 & 2 & 0.4 & 0.409 & 0.516 & 1.000 \\
\hline $\begin{array}{l}\text { Even if we do not have signs of the disease, we must keep our } \\
\text { social distancing }\end{array}$ & 454 & 100 & 0 & 0 & 0 & 0 & - & - & - \\
\hline $\begin{array}{l}\text { We should clean frequently used surfaces such as door handles, } \\
\text { faucets and sinks every day with water and detergent }\end{array}$ & 446 & 98.2 & 7 & 1.5 & 1 & 0.2 & 0.030 & 0.084 & 0.616 \\
\hline $\begin{array}{l}\text { We should definitely wash our hands after contact with potentially } \\
\text { dirty surfaces }\end{array}$ & 454 & 100 & 0 & 0 & 0 & 0 & - & - & - \\
\hline A healthy person does not need to wear a face mask & 15 & 3.3 & 4 & 0.9 & 435 & 95.8 & 0.067 & 0.100 & 0.084 \\
\hline Serious disease will not develop in every individual with COVID-19 & 187 & 41.2 & 90 & 19.8 & 177 & 39.0 & 0.011 & 0.552 & 0.249 \\
\hline COVID-19 danger is as high as that of seasonal flu & 13 & 2.9 & 52 & 11.5 & 389 & 85.7 & 0.073 & 0.410 & 0.081 \\
\hline $\begin{array}{l}\text { I do not need to take additional measures to prevent COVID-19 } \\
\text { contagion }\end{array}$ & 4 & 0.9 & 9 & 2.0 & 441 & 97.1 & 0.055 & 0.641 & 0.300 \\
\hline
\end{tabular}

knowledge because they are in direct contact with patients, both in their courses and in their training in health institutions.

We identified that television was the main source of information about COVID-19 for more than $43 \%$ of the students $(n=201)$. This finding is consistent with that of other research in students, who chose mass media to obtain general information about SARS. ${ }^{14}$ However, the fact that more than $21 \%$ of students $(n=100)$ use social media as their primary source of information is a major concern. It is highly important for unbiased and reliable information about COVID-19 infection to be obtained.

Currently, scientists who are experts in their field are frequently featured on TV shows, and valuable knowledge regarding the prevention and control of current pandemic is shared. However, there is a wide range of malicious information, especially on social networks, which is rapidly spreading and can mislead people. Therefore, information on COVID-19 should be carefully evaluated and media with scientific content should be used as source of information.

The results of this study show that part of the information available on COVID-19 is incorrect and incomplete. Many participants did not know about the incubation period $(85.5 \%)$ and the place of antibiotics in first-line treatment $(38.1 \%)$. There were also important deficiencies regarding the knowledge about the effectiveness $70 \%$ alcohol (33.3 \%) and transmission via mosquito bites (18.5\%). Respiratory infections have been the most common reason for prescribing antibiotics in the primary care setting for many years, ${ }^{15}$ which is unfortunate because antibiotics are inappropriately prescribed despite the absence of proven bacterial infection, and growing knowledge that there may be solutions for viral infections throughout the community. For this reason, we need to increase our awareness as a society about the correct use of antibiotics. It is also important to encourage the development of knowledge in students of health-related departments, who can play an active role in preventing such epidemics in the future and in current disease, which continues to have a globally destructive effect. As suggested by Drake et al., ${ }^{16}$ there is a need for a societal learning method whereby the burden of infections with global pandemic risk can be effectively reduced.

\section{Conclusions}

According to the results of our study, students from a vocational health school were found to have good knowledge and a positive attitude towards COVID-19. Although the participants were shown to possess sufficient information, there are still shortcomings and inaccuracies in some aspects. Issues such as risk 
factors for the disease and the effect of close contact on the spread of the disease are known, and most participants apply infection prevention measures. The main sources of information for the students were television and social networks. In line with these results, the development of new policies to encourage students to use science-based information resources should be considered.

\section{Conflict of interests}

None.

\section{Funding}

This research did not receive any specific grants from public or commercial sector agencies or non-profit entities.

\section{Ethical disclosures}

Protection of human and animal subjects. The authors declare that no experiments were performed on humans or animals for this study.

Confidentiality of data. The authors declare that no patient data appear in this article.

Right to privacy and informed consent. The authors declare that no patient data appear in this article.

\section{References}

1. Yin $Y$, Wunderink RG. MERS, SARS and other coronaviruses as causes of pneumonia. Respirology. 2018;23:130-137.

2. Zhu N, Zhang D, Wang W, Li X, Yang B, Song J, et al. A novel coronavirus from patients with pneumonia in China, 2019. N Engl J Med. 2020;382:727-733.

3. Hasöksüz M, Kiliç S, Saraç F. Coronaviruses and SARS-COV-2. Turk J Med Sci. 2020;50(SI-1):549-556.

4. World Health Organization [Internet]. Coronavirus disease 2019 (COVID-19) pandemic; 2020.

5. Li Q, Guan X, Wu P, Wang X, Zhou L, Tong Y, et al. Early transmission dynamics in Wuhan, China, of novel coronavirus-infected pneumonia. $N$ Engl J Med. 2020;382:1199-1207.

6. Backer JA, Klinkenberg D, Wallinga J. Incubation period of 2019 novel coronavirus (2019-nCoV) infections among travellers from Wuhan, China, 20-28 January 2020. Euro Surveill. 2020;25:2000062.

7. Cascella M, Rajnik M, Cuomo A, Dulebohn SC, Di Napoli R. Features, evaluation and treatment coronavirus. USA: StatPearls Publishing; 2020.

8. Wang X, Fang X, Cai Z, Wu X, Gao X, Min J, et al. Comorbid chronic diseases and acute organ injuries are strongly correlated with disease severity and mortality among COVID-19 patients: a systemic review and meta-analysis. Research. 2020;2020:2402961.

9. Ashour HM, Elkhatib WF, Rahman MM, Elshabrawy HA. Insights into the recent 2019 novel coronavirus (SARS-CoV-2) in light of past human coronavirus outbreaks. Pathogens. 2020;9:186.

10. Bhagavathula AS, Aldhaleei WA, Rahmani J, Mahabadi MA, Bandari DK. Knowledge and perceptions of COVID-19 among health care workers: cross-sectional study. JMIR Public Health Surveill. 2020;6:e19160.

11. Conley L, Tao Y, Henry A, Koepf E, Cecchini D, Pieracci J, et al. Evaluation of eco-friendly zwitterionic detergents for enveloped virus inactivation. Biotechnol Bioeng. 2017;114:813-820.

12. Kampf G. Efficacy of ethanol against viruses in hand disinfection. J Hosp Infect. 2018;98:331-338.

13. Tooher R, Collins JE, Street JM, Braunack-Mayer A, Marshall H. Community knowledge, behaviours and attitudes about the $2009 \mathrm{H} 1 \mathrm{~N} 1$ influenza pandemic: a systematic review. Influenza Other Respir Viruses. 2013;7:1316-1327.

14. Bergeron SL, Sánchez AL. Media effects on students during SARS outbreak. Emerg Infect Dis. 2005;11:732-734.

15. Harris AM, Hicks LA, Qaseem A, High Value Care Task Force of the American College of Physicians and for the Centers for Disease Control and Prevention. Appropriate antibiotic use for acute respiratory tract infection in adults: advice for high-value care from the American College of Physicians and the Centers for Disease Control and Prevention. Ann Intern Med. 2016;164:425ロ434.

16. Drake JM, Chew SK, Ma S. Societal learning in epidemics: intervention effectiveness during the 2003 SARS outbreak in Singapore. PLoS One. 2006;1:e20. 